Meta

Journal des traducteurs

Translators' Journal

\title{
Translation Studies - The State of the Art
}

\section{Wolfram Wilss}

Volume 49, numéro 4, décembre 2004

URI : https://id.erudit.org/iderudit/009781ar

DOI : https://doi.org/10.7202/009781ar

Aller au sommaire du numéro

Éditeur(s)

Les Presses de l'Université de Montréal

ISSN

0026-0452 (imprimé)

1492-1421 (numérique)

Découvrir la revue

Citer cet article

Wilss, W. (2004). Translation Studies - The State of the Art. Meta, 49(4),

777-785. https://doi.org/10.7202/009781ar

\section{Résumé de l'article}

La traduction est une nécessité première pour faire face à l'avenir et acquérir des connaissances nouvelles. Non seulement elle facilite la compréhension des structures socioculturelles, des systèmes économiques et politiques et de l'évolution technique et technologique, mais elle a aussi contribué à diffuser la connaissance du monde (incluant notre conscience de "l'Autre ») dans un ensemble d'interrelations sociales et culturelles et a élargi notre horizon (inter-)linguistique et (inter-)culturel.
Ce document est protégé par la loi sur le droit d'auteur. L’utilisation des services d’Érudit (y compris la reproduction) est assujettie à sa politique d'utilisation que vous pouvez consulter en ligne.

https://apropos.erudit.org/fr/usagers/politique-dutilisation/ 


\title{
Translation Studies - The State of the Art
}

\author{
WOLFRAM WILSS \\ University of the Saarland, Saarbrücken, Germany
}

\begin{abstract}
RÉSUMÉ
La traduction est une nécessité première pour faire face à l'avenir et acquérir des connaissances nouvelles. Non seulement elle facilite la compréhension des structures socioculturelles, des systèmes économiques et politiques et de l'évolution technique et technologique, mais elle a aussi contribué à diffuser la connaissance du monde (incluant notre conscience de «l'Autre») dans un ensemble d'interrelations sociales et culturelles et a élargi notre horizon (inter-)linguistique et (inter-)culturel.
\end{abstract}

\section{ABSTRACT}

Translation has spoken with growing impact and urgency to mankind for more than two millennia. Not only has it facilitated the understanding of sociocultural structures, economico-political systems, and technological/technical processes; it has also pushed forward our knowledge of the world (including our awareness of "otherness") and widened our (inter-) linguistic and (inter-)cultural horizon.

\section{MOTS-CLÉS/KEYWORDS}

translation studies, knowledge, client/server-relationship, computer translation

\section{Introduction}

Translation has spoken with growing impact and urgency to mankind for more than two millennia. Not only has it facilitated the understanding of sociocultural structures, economico-political systems, and technological/technical processes; it has also pushed forward our knowledge of the world (including our awareness of "otherness") and widened our (inter-) linguistic and (inter-)cultural horizon. Translation, both in the form of human activity and machine algorithms, has become so pervasive as a means of border-crossing communication that today it is globally distributed, carrying with it a heavy load of success and failure, potentialities and limitations.

This is a development with heavy consequences. Traditionally, as the (ideological) free/literal translation dichotomy makes abundantly clear, translation practitioners were rather hostile to scientific norms; rather they saw their task as the benign systematization of their own methodical approach against the backdrop of domainspecific principles which they were eager to defend (Wilss 1982).

In modern times the situation has changed tremendously. Translation is no longer considered as a bundle of subjectively authoritative performance, however legitimate the respective authority may have been, but as a tool for distributing pregiven knowledge in a new linguistic and cultural environment, thereby avoiding, as far as possible, elements of uncertainty and instability in the execution of their task. The dialectical relationship exemplified, as mentioned beforehand in the free/literal dichotomy, has been transformed into a collusive relationship, collusive referring to the interdependence between source text, translator, and target-text recipient. 
So much is common and hopefully uncontroversial ground. Things become more entangled when we look at the "translation community," individual translators, translator collectives and organizations, and, last but not least, translation researchers. People from the most divisive strands of life increasingly enter the scene of translation-based knowledge and translation-based knowledge studies.

\section{Knowledge and Translation}

Today, the crucial term in the translational context is knowledge. The respective client of a respective translator does not only demand just knowledge, but knowledge tailored to his specific requirements and needs. This means that the translator, be he LSP, literary or Bible mediator, is forced to acquire expert knowledge which he must have at his immediate disposal or access through the resources available for background research.

However, it would be misleading to conclude that the rearrangement of the translational scenario is merely the outcome of change in the overall world-view or the new techno-cultural composition of society; nor are these changes produced simply by the gradual, but inexorable subordination of translation to new sociocultural, economic-political, and industrial imperatives. As Nowotny et al. have convincingly shown in their simulating and thought-provoking book "Re-Thinking Science" (2002), a more fundamental shift in modern society is underway. The worldwide transformation society and, as a consequence, in translation (left out in Nowotny's argumentation), is the result of a general shift from collective beliefs and values towards more individual beliefs and values. Equally important is the intensified cooperation between economics and industry on the one side, and society with its highly competitive characteristics on the other. In modern society at large, individualisation has been in the ascendant for a long time. This development has, of course, left its traces in translation. In the wake of emerging computer literacy, new forms of translation expertise have become not only desirable, but also possible.

\section{Client/Server-Relationship}

So far, translation has been seen as a continuous process largely dominated by the absence of interaction between the translator profession and the public. But now, different types of users of translations have entered the picture: potential markets, which are locally, regionally, or globally organized, have fostered client/serverrelationship, with clients representing the public and servers representing the translator profession, both together striving for translation optimization in terms of speed and quality, thereby being more conscious of translation services funding than previously.

An obvious example of the new attitude of the public towards translation products and translation methods is the debate in the EU on which language policy will be needed in order to cope with the huge amount of translations expected to flood EU authorities after East European EU-access. New nationalistic issues and dilemmas, such as speed versus quality, will arise in view of the agonizing fact that no EU-accepted guidelines are as yet in place or at least recognizable along the EU linguistic horizon. The growing power of world communication intervenes in national 
communication, drawing attention to what translators do and what their contribution to international communication will be.

\section{Computer Translation}

There is growing interest in the fact that translators willy nilly are learning how to take full advantage of the opportunities offered by the new entrepreneurial environment which is heavily interspersed with all sorts of electronic data-processing equipment. Seen in a long-term future-oriented perspective, the reality-shaping power of computer technology has become a predominant feature of electronically advanced societies. This process is accelerating. In former times, electronic data-processing could claim only one function, namely that of speeding up simple mental operations. Today, the computer is multifunctional, its overriding function being to act as the driving force in creation and innovation and to sustain the trend towards the electronic simulation of human activities, including translation.

After a sequence of fashionable ups and downs, computer translation research has taught us that, as a rule, and with the exception of highly standardized texts, translation problems cannot, at least not in an encompassing way, be solved by conventional algorithms. Translation problems must be solved by heuristic procedures that for the most part do not operate in a standard fashion. There is no intrinsic coherence between stimulus and response sequences. The solution of translation problems requires a fair amount of cognitive insight, but very little in the way of prior algorithmic knowledge. Infinite regularization of translation procedures is not a reality. Translation is always a compromise between two opposed and conflicting forces: systematization and contingency. Computer translation operations are not isomorphic with human translation behaviour, which has directly observable components and direct text criteria against which the output of translators can be checked. In computer translation research, many basic problems are as yet unsolved. Hence it is too hazardous to predict what computer translation will contribute to the facilitation of the international exchange of information.

Translation is not only an occasion for routine communication with repetitive and predictable qualities, but also, and at a higher rate, an occasion for creatively reproducing novel utterances which tenaciously resist any attempt at regularization and predictability - with the exception of "translation memories" which are being developed for standard communication in the field of LSP and administration (Wilss 1996; 2000). This is a state of affairs which shows that many things of importance that can be said about translation can appropriately be stated in terms of cognitive psychology (including computer science). This does not mean that translation research, or, for that matter, translation studies do not have their own theoretical basis, their own objectives, methodology, and self-contained range of applications. What is required of translation practitioners, translation teachers and translation scholars, is a combination of experimental and experiental thinking, of flexibility and inventiveness, allowing permanent interplay between skilled translator performance and stored knowledge bases in the area of knowing what for (for whom), knowing what and knowing how (Ryle 1949).

Seen from this angle, the mechanization of translation seems to be a core candidate for translation research, but prospects for progress are not very encouraging. 
The principal impediment to computer translation is that the computer or, rather, the computer programme, does not "understand" a source text; nor are there efficient transfer programmes.

Concepts such has novelty, incongruity, and complexity are impossible for the computer to handle. Hence the emphasis by Torrens on "the slow reduction of the very long distance to be covered before attaining satisfactory performance where intelligibility can be simply taken for granted" (Torrens 1994: 390). We all know that in understanding (and reproducing) a linguistic utterance in context, three (interactive) levels of comprehension must be distinguished: syntactic, lexical and pragmatic understanding (Enkvist 1987). Of these three levels or areas of understanding, computer programmes can cope with syntactic properties to a considerable degree, semantic (lexical) properties to some degree, and pragmatic (contextual) issues to zero degree. The challenge for translation-related computer research is to develop machine-translation programmes which are able to simulate the ability of the human translator to extract the meaning of the words and sentences that form a text. Here artificial intelligence comes in, because one of the chief targets of artificial intelligence experts is to conceive of formalized strategies which enable the computer to behave in a quasi-human manner.

\section{The Differentiation of Translation Studies}

Contrary to the former trend for uniformity and homogeneity in translation model building, there is now an opposite, or, rather, a parallel trend in TS, and this is the explosion of the translation scenario into diversity and heterogeneity, creating a new knowledge environment in which many researchers with different perspectives and interests are eager to find new solutions for old problems. Formerly the role of the TS scholar was characterized not by disciplinary norms and professional values but by shaping and reshaping - sometimes approaching the limits of triviality - theoretical models of the translation process. Collectivists, abstract conceptualizations of the translation process were dominant. Rewards and sanctions were determined, ridiculously, according to the adherence - or non-adherence - to the self-styled TS schools which were organized and controlled by the benevolence or male-volence of TS meritocracy.

In the TS community, there is now, not least by the impact of machine and machine-aided translation, a shift in the mode of scientific thinking in which results are no longer pre-fixed (prescribed) and predictable. The management of TS has correspondingly become more complex. Evidence for this can be gathered, e.g. from the TL series (now approaching 50 titles) of John Benjamins and from META successfully managed for many years by the former director of the Montréal translation school, Professor André Clas.

TS research is now directed towards a multitude of targets and, as a result, research priorities are constantly shifting. In response to this development, TS research has turned away, at least to a large extent, from "top-down" (theoretical) towards "bottom-up" (empirical/applied) research. New research activities have sprung up in cognitive theory (Krings 1986; Wilss 1988; Tirkkonen-Condit 1993, to name just a few) populated by different kinds of experts with different skills and experience. There is 
now a strong belief that a wide spectre of TS activities is indispensable for solving problems which are far beyond the traditional array of subject-matters.

\section{The Role of the Translator in the Translation Process}

So far, the professional translator has been under-represented in our line of argumentation, be it as the object of study or as the person active in doing translation research. It is largely due to the emergence of TAP experiments (TAP $=$ ThinkingAloud Protocols) which started with the above-mentioned book by Krings (1986) that the importance of his role in his job has gained in relevance. It is much more widely recognized than previously that the translator as an object of TS, be he or she gendered or in some other way socially categorized, has to be attended to, if TS results are not to be unnecessarily restricted in their validity or made somewhat useless in their applicability (Wilss 1996).

Metaphorically speaking, translators are a kind of "displaced persons" who plug their own communication system into the translation network, hoping that in the course of their activity they can gradually filter out the uncertainty which makes itself unpleasantly felt in many translation processes. A translator is supposed to be a bridge between linguistic and cultural communities, but at the same time is different from both the source-text author and the target-text reader(ship). Especially in the translation of poetry, translators often cannot reproduce the source text's intended meaning, and even if by some feliticious accident they manage to do it, they still would not be certain they had done so, because a poem as a rule has a "private" meaning rather than a public "meaning." It is perhaps with this "private" meaning in mind that Karl Dedecius, a famous Polish-German translator, has called the literary translator a "Pfadfinder der Hölle der Sprache" (boy scout of the hell of language). Less emphatically, Bolinger, referring to Steiner's book “After Babel” (1975), sees the function of translation as "the easing of otherness or alternaty" (Bolinger 1976: 28). Everyone who translates ventures into the unknown, leaving his or her own familiar environment behind, he or she starts exploring the textual surroundings in terms of situational constraints. These are different kinds, allowing the translator to practice a behaviour ranging from "hypo-correct" via "correct" to "hyper-correct." Taking one of the three options may be a calculated risk, depending on a feeling of situational appropriateness.

\section{Translation-Teaching}

Apart from the importance of a more "personalized" form of TS, there is another aspect of translation-in-context, and that is - predominantly or exclusively - the two-tier system of translators (less so of interpreters), each tier with its own entry and standards and range of academic programmes and projects. Such binary systems have been - and still are - maintained, particularly in Germany with a traditional university degree (Diplomübersetzer / Diplomdolmetscher with a capital D), and a vocational-training degree (Fachhochsculübersetzer/dolmetscher) offered by the Fachhochschulen (technical colleges, not technical universities), both degrees with a clearly noticeable and uncompromisingly intended social clue (four-year versus 
three-year programme). However, the demarcation between the two classes of academic institutions shows signs of blurring, particularly concerning the monopoly of PhD-programmes of the university-leven institutions. Political pressure, coming mostly from the SPD and the Greens, has favoured the dissolution of any hardand-fast demarcation within two-tier systems. Substantial research, above all in the field of language-technological research, has developed on the campuses of the Fachhochschulen (FHs), and occasionally the observer of the scene gains the impression that FH TS is more modernly advanced than that in traditional universities. Symptomatic of the upward drift of FHs is their renaming into "College/Institutes of Applied Sciences." An important implication of this form of "scientification" of FH courses is that in the field of funding, the FHs tend to receive the lion's share of public money, a fact which certainly does not strengthen the academic commonality between universities and FHs and attempts at institutional uniformity.

This tension between the desire to preserve or enhance scientific "excellence" (which has recently become a catchall word in German) and vocational (professional) "excellence," between theory and practical "access," is somewhat hampering the leap forward of TS, but it seems to be on the way out. The future of TS suggests a wide spectre of complex interaction between academic learning and professional issues, between constraints and stimulants, between the translator as a problem-solvingoriented person and as a mere routinier, responsible only for more or less mechanical transfer (on the basis of automatically functioning one-to-one correspondences).

\section{The Trend Towards the Objectification of the Translation Process}

It seems to be clear from recent TS evidence, that the search for the absolute or nearabsolute truth, exemplified by the grossly overestimated "skopos-theory," is gradually being replaced by more pragmatic research issues and research goals, abandoning the rather arrogant claim to reveal the ultimate solution to all translation problems. TS, like any "soft-science" discipline, is to a large extent uncertainty-bound. What is detrimental rather than conducive to TS, are grand assertions of having discovered the once-and-for-all theory of translation, guaranteeing objectivity across translationrelated textual domains. The concept of objectivity in TS, and for that matter in translation practice, is a many-layered, pluri-facettes issue with a lot of fuzzy edges. I am referring here to the insightful work by John Ziman who, particularly in his 1991 book on "Reliable Knowledge: An Exploration of the Grounds for Belief in Science," has plausibly stated:

[...] scientific knowledge is the product of collective human enterprise to which scientists make individual contributions which are purified and extended by mutual criticism and intellectual cooperation (Nowotny et al. 2002: 170).

Ziman argues - and this is a powerful argument against pseudo-scientific jargon deplorably often manifest in TS literature - (Wilss 1979) - that a scientific message, whether theoretical in nature or based on empirical findings, should strive for a maximum degree of consensuality. But striving for consensuality and reaching consensuality are not always the top priority of research, at least not in TS. Many TS in their day-to-day performance seem to be content with rather limited consensus from colleagues in their disciplinary scientific community. TAPs, e.g., reveal that 
there rarely exists a maximum degree of acclaim. The reason for this is quite obvious. The basic trouble with TAPs, stimulating as they are in many respects, is that no generic techniques for the analysis of thinking-aloud procedures have so far been identified (at least to my knowledge) and normatively applied to a representative sample of translation-bound texts. Hardly any LSP texts have been subjected to rigorous thinking-aloud procedures. (In this domain, the development of "translation memories" seems to be much more important (Wilss 2000)) Of course, a good deal of consensuality can be achieved intuitively, if we mean by intuition the outcome of mutually accepted tacit knowledge as a prerequisite for consensuality.

\section{The Future of the Translation Industry}

The future of the translation industry is probably closely interconnected with the growth of the knowledge industry and concomitant knowledge society (Drucker 1994; te Haan/Poltermann 2002). The proliferation of (translation-relevant) knowledge and the required need for knowledge management is probably the core of the modernization of society. Modernization, the contemporary catchword, cannot be attributed to the prevailing of a "hidden hand" or to other apparently impersonal factors (Wilss, in press). Rather, as publicly on display for everyone to see, modernization is the overarching manifestation of mankinds' control over nature and nurture (i.e. social engineering).

This has not always been the case. At the turn of the century (from the 19th to the 20th century), thinking and acting in terms of modernity was a largely cultural phenomenon, the so-called "Moderne" with its emphasis on art, architecture, literature, etc. But soon after its triumphant emergence, the "Moderne" began to run against its own limits and onesidedness, opening the way for a primarily technical concept of modernization, the birth of which we may associate with the end of World War II in Europe and, a few months later, the annihilation of Hiroshima.

At the same time, economic and technological resources, until then mostly under national control, underwent an Anglo-American dominated process of internationalization marked by the development of new information and communication technologies (ITs). In their wake, translation activities condensed into a veritable translation industry (just as the acquisition of foreign-knowledge knowledge turned into an equally veritable language industry with the positioning of English as world language number one). New translation training centres and translation services sprang up all over the world. At an increasing scale they affect international production systems whose top priorities are flexibility, just-in-time organization, and lean production (Wilss 1999).

The correspondence between the evolution of new economic structures, political configurations and sociocultural settings on the one hand and new international communication networks on the other is too suggestive to perceive as purely accidental. The rise of techno-cultural modernization is a lasting reflection of factors which for the most part have been widely explored and described. What has received less attention is the rise of international communication which reflects the metamorphosis from local via regional to global information, with the ensuing increase in the translator labour market. The greatest growth has occurred, and is occurring, in the field of software translation, following the principle high quality, low cost, high-tech. 
Contemporary software is characterized - probably irreversibly - by diversity, volatility, and internationality. Software packages cannot be understood in terms of globally prevailing norms, but must be seen as a manifestation of "globalization." Cumulatively, the traditional categories of human experience and enterprise, science, culture, have given way to technologies that completely overturn established translator training programmes which are quickly becoming obsolete.

\section{Conclusion}

In the most encompassing sense, translation, and above all software translation as a fast-growing part of LSP translation, has to be regarded in an instrumental-utilitarian mode, including technological innovation, economic competitiveness, functional differentiation, and global transgressivity. Translation, as an industry, is today valued for its capacity to create, on the basis of pre-given data, new knowledge and deliver a continuous stream of expert information which the potential recipient can exploit for its own purposes.

International knowledge transfer is today a major subject with a vascillating balance between demand and supply, between training and professional behaviour. Regionalization and globalization have enormously stretched the boundaries of international communication. Nation-states can no longer rely on old-established patterns of insufficiently permeable patterns of international knowledge transfer. The international arena is now fairly comprehensively furnished with international institutions taking care of providing the market with expert translators who are able to work with the required efficiency.

In this process, the highly specialized and differentiated system of modernity is playing a major role. The rapid development of electronically controlled and digitally organized new information and communication channels has entailed, with an expected but unwelcome side-effect, the tightening of bureaucratic restrictions. Today the translation industry has seen, and is seeing, at a tremendous speed the re-moulding of the translator profession striving at lean production, new shapes, patterns, and formats within the framework of horizontally dispersed structures. The observed changes in international communication clearly show a number of transfer parameters that suggest similarities and dissimilarities in the operative field. They point to clusters of factors typically linked in a highly dynamic mode.

One aspect of this new process threatening the existence of the translator profession is the keyrole of uncertainty (Wilss, in press). The profession must be prepared to accept uncertainty, or risks, for that matter, as crucial elements of translation action and translation decision-making (Wilss 1988; 1996), realizing that it is difficult, or even impossible, as TAPs show, to disentangle the complexities of decisionmaking and make a clear distinction between rational and irrational (decisionist / dezisionistisch) decision-making. At present, we do not know how to cope fully with unwanted and potentially harmful consequences of uncertainty in translation work.

At stake is the awareness of the fact that the translation professional (much more than the translation theorist traditional) must try to develop an innovative potential of methods allowing the transmission of knowledge which can profitably be implemented in a number of different directions and translational scenarios. 


\section{REFERENCES}

Bolinger, D. (1976): “Review of Steiner," Language Sciences 43, pp. 28-31.

Drucker, P. F. (1994): “The Rise of the Knowledge Society,” Dialogue 2, pp. 13-18.

Enkvist, N. E. (1987): "More about Text Strategies," in Lörscher, W. and R. Schulze (eds.), Perspectives of Language Performance. To Honour Werner Hüllen on the Occasion of his Sixtieth Birthday. Tübingen, Niemeyer, pp. 337-350.

HaAn, G. De und A. Poltermann (2002): Funktion und Aufgaben von Bildung und Erziehung in der Wissensgesellschaft, Berlin, Veröffentlichung der Forschungsgruppe Umweltbildung an der Freien.

KrIngs, H. P. (1986): Was in den Köpfen von Übersetzern vorgeht. Eine empirische Untersuchung zur Struktur des Übersetzungsprozesses an fortgeschrittenen Französischlernern, Tübingen, Narr.

Nowotny, H., Gibвons, M. and P. Sсотт (2002): Rethinking Science: Knowledge and the Public in an Age of Uncertainty, Cambridge UK, Polity.

Ryle, G. (1949): The Concept of Mind, London, Hutchinson.

Steiner, G. (1975): After Babel. Aspects of Language and Translation, London, Oxford University Press.

Tirkкonen-Condit, S. (2000): Uncertainty in Translation Processes, in Tirkкonen-Condit, S. and R. JÄÄskeläInen (eds.), Tapping and Mapping the Processes of Translation and Interpreting. Outlooks of Empirical Research, Amsterdam/Philadelphia, John Benjamins, pp. 123-142.

Torrens, A. (1994): "Machine Translation Evaluation and Quality Benchmarks," Terminologie et Traduction 1, pp. 375-415.

Wilss, W. (1979): Fachsprache und Übersetzen, in Felber, H. et al. (eds.), Terminologie als angewandte Sprachwissenschaft, München, Saur, pp. 177-191.

WiLss, W. (1982): The Science of Translation. Problems and Methods, Tübingen, Narr.

Wilss, W. (1988): Kognition und Übersetzen. Zu Theorie und Praxis der menschlichen und der maschinellen Übersetzung, Tübingen, Niemeyer.

Wilss, W. (1996): Knowledge and Skills in Translator Behaviour, Amsterdam/Philadelphia, John Benjamins.

WiLss, W. (1999): Translation and Interpreting in the 20th Century. Focus on German, Amsterdam/ Philadelphia, John Benjamins.

Wilss, W. (2000): Wandlungen eines Universitätsinstituts. Vom "Dolmetscherinstitut" zur Fachrichtung "Angewandte Sprachwissenschaft sowie Übersetzen und Dolmetschen," St. Ingbert, Rörig.

Wilss, W. (in press): Der Begriff der Modernisierung in der deutschen Gegenwartssprache.

Wilss, W. (in press): The Impact of Uncertainty on Translation.

Ziman, J. (1991): Reliable Knowledge: An Exploration of the Grounds for Belief in Science, Cambridge UK, Cambridge University Press. 